\title{
THE NEW DEVELOPMENT TREND OF OPERATIONAL RESEARCH IN CIVIL ENGINEERING AND SUSTAINABLE DEVELOPMENT AS A RESULT OF COLLABORATION BETWEEN GERMAN-LITHUANIAN-POLISH SCIENTIFIC TRIANGLE
}

\author{
Jolanta Tamošaitiené ${ }^{1}$, Lina Bartkiené2, Tatjana Vilutiené $\dot{e}^{3}$ \\ Vilnius Gediminas Technical University, Sauletekio ave. 11, LT-10223 Vilnius, Lithuania

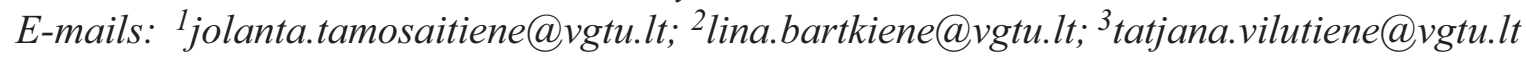

Received 26 November 2009; accepted 12 March 2010

\begin{abstract}
In this article the scientific cooperation between the three academic centres from Germany, Lithuania and Poland, represented by Prof. F. Peldschus (Leipzig University of Applied Sciences), Prof. E. K. Zavadskas (Vilnius Gediminas Technical University), and Prof. O. Kapliński (Poznan University of Technology), is presented. Formal meetings have been called Colloquia, and were organized every two years in different academic centres.

The research achievements and activities during the period of 2007-2009 are presented. The main research fields of OR in Civil Engineering and Sustainable Development of three academic centres are surveyed. As a result of productive collaboration in the period between the 11th and 12th Colloquiums, several postdoctoral theses and doctoral dissertations were defended, research papers and books were published and conferences were organized with published proceedings, etc. On the basis of these achievements EURO Working Group OR in Sustainable Development and Civil Engineering (EWG-ORSDCE) was established.
\end{abstract}

Keywords: collaboration, sustainability, operational research, civil engineering, development.

Reference to this paper should be cited as follows: Tamosaitiene, J.; Bartkiene, L.; Vilutiene, T. 2010. The New Development Trend of Operational Research in Civil Engineering and Sustainable Development as a result of collaboration between German-Lithuanian-Polish Scientific Triangle, Journal of Business Economics and Management 11(2): 316-340.

\section{Introduction}

Active collaboration between German - Lithuanian - Polish scientific triangle caused the new development trend of research. The research areas till 2009 were limited to Operational Research (OR) and Civil Engineering. Prof. E. K. Zavadskas raised the idea to analyse Operational Research and Civil Engineering in the context of sustainability. These issues were analysed at the $12^{\text {th }}$ colloquium. As the consequence of new trend of research development the EURO Working Group OR in Sustainable Development and Civil Engineering (EWG-ORSDCE) was established. 


\section{The idea and development of German-Lithuanian-Polish scientific triangle}

During thirty years of scientific cooperation of three academic centers, i.e. Leipzig University of Applied Sciences, Vilnius Gediminas Technical University and Poznan University of Technology, due to the main initiators Prof. E. K. Zavadskas, Prof. F. Peldschus and Prof. O. Kapliński the active collaboration has started. Collaboration in exchanging of research achievements, consulting on publications, cooperating in joint papers, supporting the future research was realized through organization of colloquiums, which were held every two years in different academic centres (Kaplinski 2009a).

Five of mentioned colloquiums were organized in Germany, four held in Lithuania and three in Poland. Every colloquium from the first one held in 1986 and to the last had given the considerable contribution to the publication of research papers and books, development of further academic research, preparing doctoral dissertations and for international recognition (Fig. 1).

The initiating members of the first colloquium held in 1986 were Prof. K. Fiedler (Leipzig Higher Technical School), Dr F. Peldschus (Leipzig Higher Technical School) and Dr E.

K. Zavadskas (Vilnius Civil Engineering Institute). The second colloquium was held in 1989 and representative from Poland Prof. O. Kaplinski was invited (Zavadskas 2008b).

The $11^{\text {th }}$ German-Lithuanian-Polish Colloquium "Planning Instruments in Construction Management", which took place in Kołobrzeg, Poland in 2007, was organized by Poznan University of Technology. The major theme of this colloquium was planning instruments in construction management (Zavadskas 2008e).

There were also other subjects analysed such as development and usefulness of planning techniques, intelligent green construction, investment problems in cooperating countries, artificial intelligence, facility management, life cycle of objects, achievements and application of Multi-Criteria Decision Analysis (MCDA) and Multi-Criteria Decision Making (MCDM) methods (Kapliński 2010).

In the colloquium further research on the aspects of operational research methods, sustainable development and its application for problem solution in civil engineering was initiated. The $11^{\text {th }}$ colloquium was exceptional due to aspiration to make the achievements of colloquiums known to the scientists of other European Union countries, and the idea to create the working group of "Operation Research in Sustainable Development and Civil Engineering" has originated. Prof. E. K. Zavadskas on the basis of his long-term scientific research, with his former PhD students, now colleagues, initiated the implementation of the mentioned idea.

This purpose required further cooperation in the area of Sustainable Development and Construction problems (Zavadskas 2008b). The mentioned area was the core topic of the $12^{\text {th }}$ colloquium, which was organized by Vilnius Gediminas Technical University.

The $12^{\text {th }}$ German-Lithuanian-Polish Colloquium was held in Vilnius, Lithuania, on 20-24 May 2009. It was entitled "Sustainable Development in Civil Engineering and 
1986

The $1^{\text {st }}$ Colloquium

2007

The $11^{\text {th }}$ Colloquium

2009

The $12^{\text {th }}$

Colloquium and establishment of EWG-ORSDCE
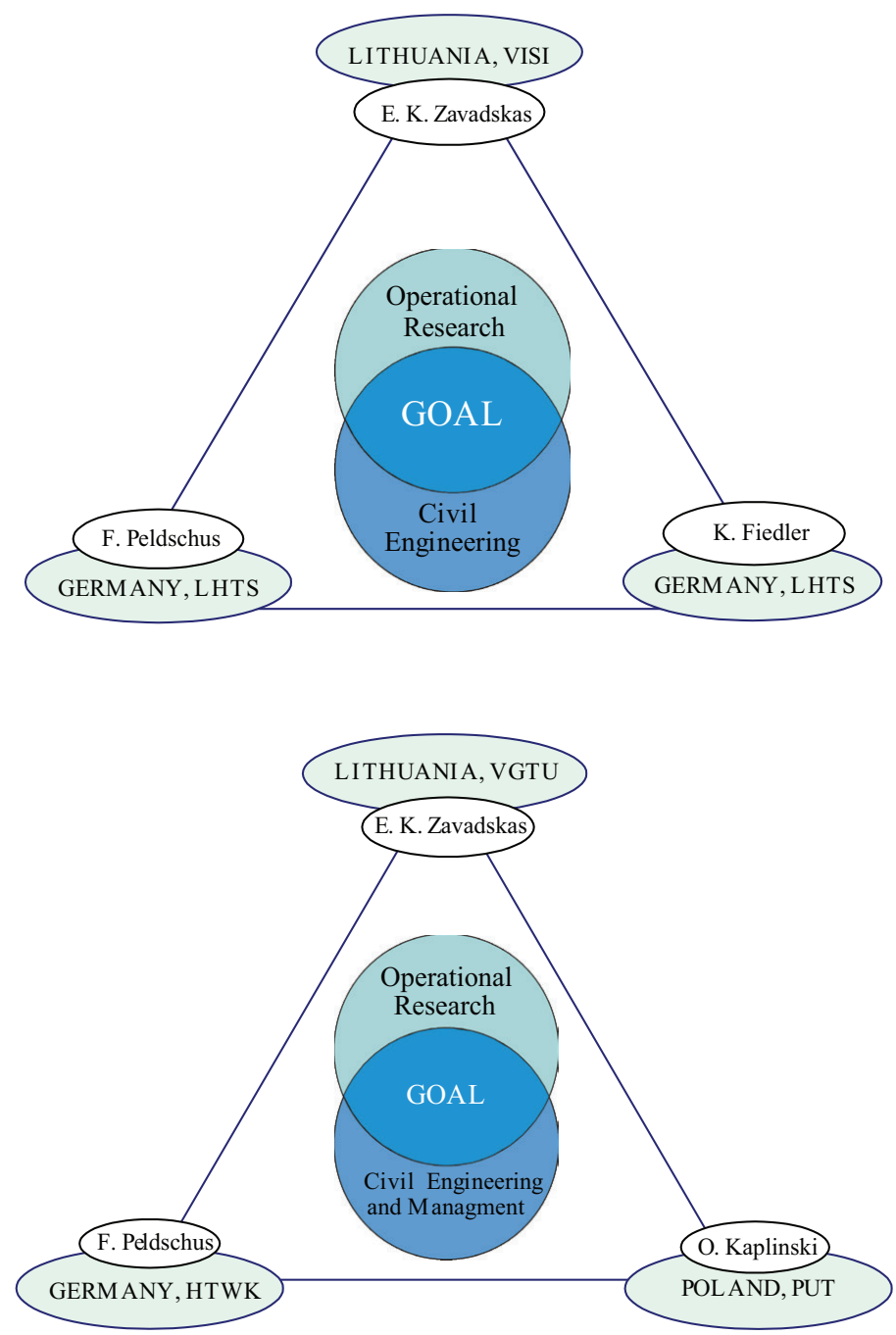

\section{EWG - ORSDCE}

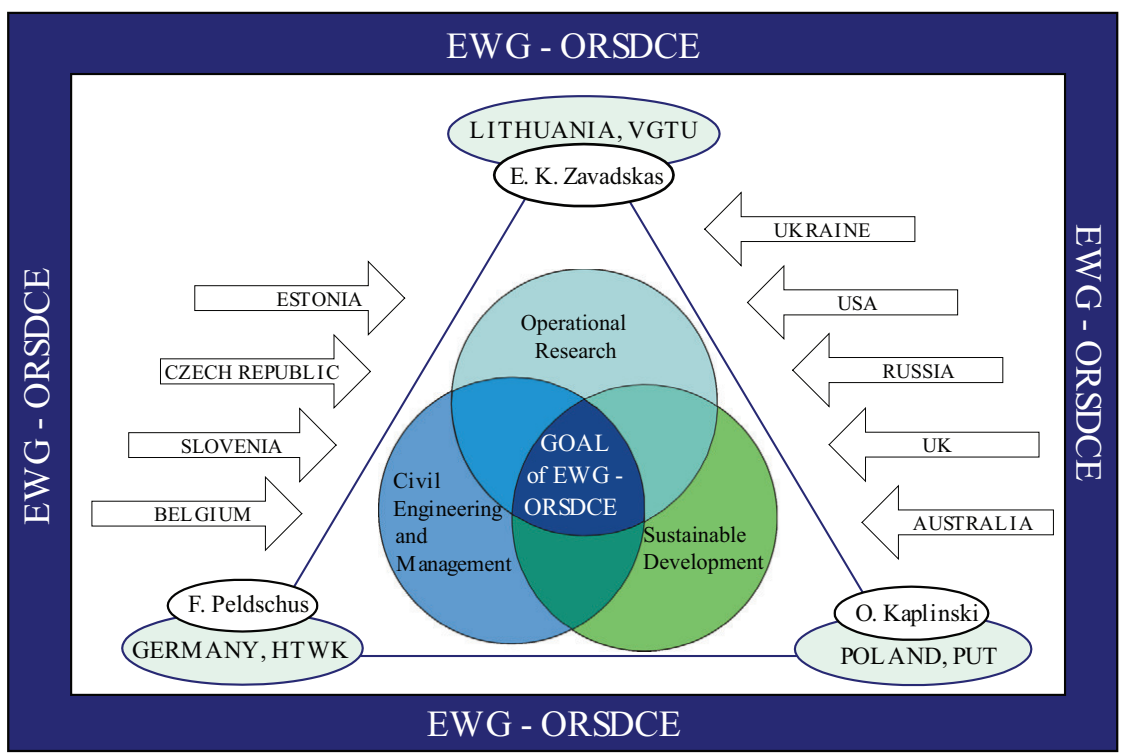

Fig. 1. Development of collaboration between three German-Lithuanian-Polish academic centres during 1986-2009 
Multi-Attribute Decision Making”. The chairman of International Programme Committee was Prof. Habil. Dr E. K. Zavadskas and responsibility to be the chairman of organizing committee was assumed by one of the first Prof. E. K. Zavadskas' PhD students, now Prof. L. Ustinovičius. The theme of colloquium covered two broadly defined areas: the first one is the development of operational research (OR) methodology and the second - Sustainable Development in Civil Engineering and Management. 56 scientists from 7 European and other countries took part in the 12th German-Lithuanian-Polish colloquium and new participants from Czech Republic, Slovenia, UK, US have joined the scientific collaboration. 43 papers were presented during the meeting and abstracts had been published (Vilutiene 2009).

As a result of unique collaboration between three academic centres during the period of 2007-2009 on the basis of aforementioned themes, the high research achievements were obtained and EWG-ORSDCE was established. The achievements during the period from the $11^{\text {th }}$ to $12^{\text {th }}$ colloquia are further analysed in the next section.

\section{The achievements and activities in scientific research during 2007-2009}

The achievements gained from 1986 until 2007 were surveyed by (Kapliński 2009a, c; Zavadskas 2008b). The productive collaboration during the period of 2007-2009 resulted in the following achievements divided into these groups: defended postdoctoral and $\mathrm{PhD}$ theses; published books, conference proceedings; organized conferences, published research papers in the journals and conference proceedings. The mentioned achievements are further analysed.

\subsection{Main aspects of research development}

The fields of the research concentrate in three broad fields (Fig. 2).

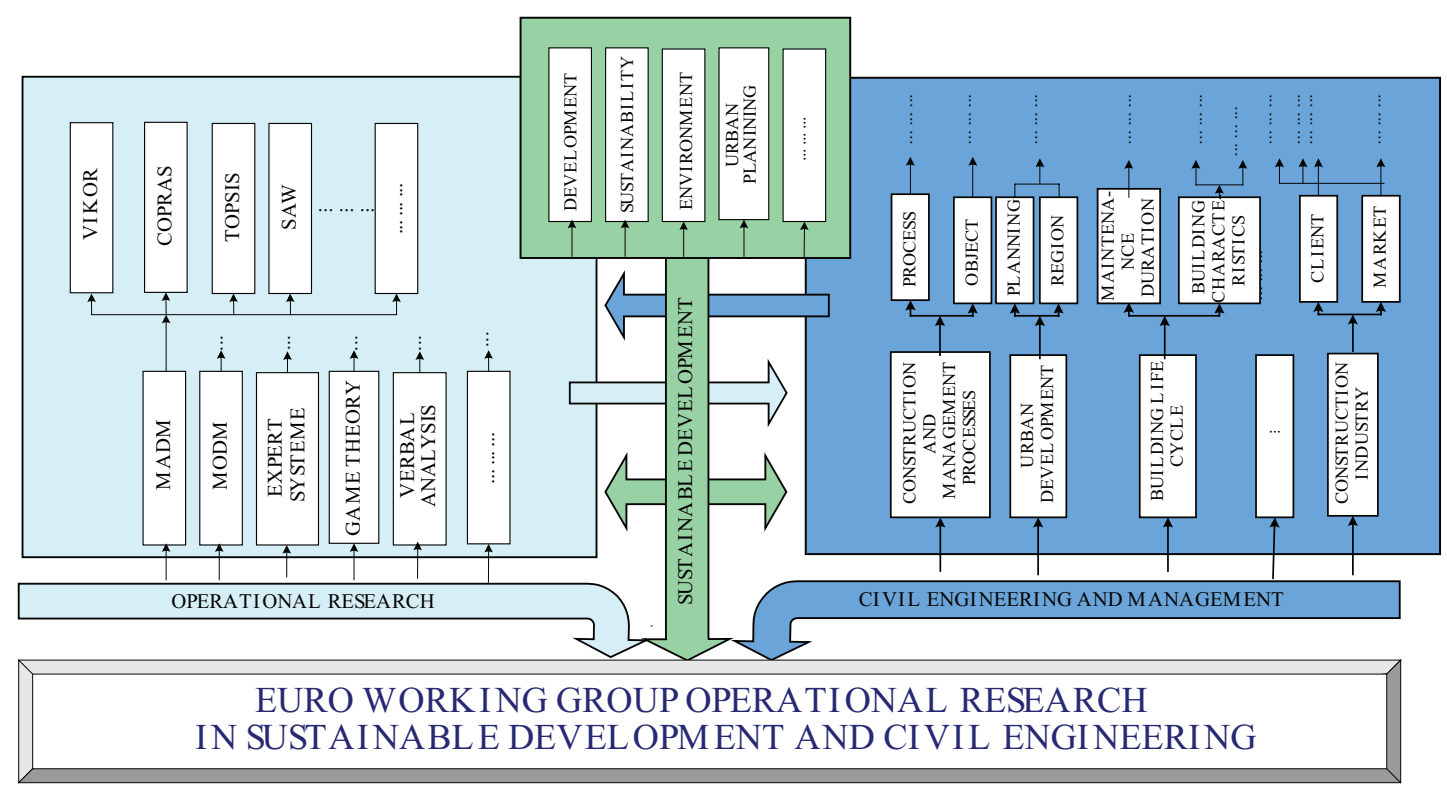

Fig. 2. The general topics of the new working group OR in Sustainable Development and Civil Engineering activities 
The fields of the research are:

1) Operational Research: operations research theory, MCDM, MADM methods, statistics, optimization, strategies, game theory, intelligent support system, etc.;

2) Civil Engineering: building life-cycle, urban development, construction and management, maintenance, approaches for construction problems', effectiveness' assessment, automation in construction;

3) Sustainable Development: developing of alternative construction processes, economic and other aspects, sustainable development challenges for business and management in construction enterprises, political influence dimensions of sustainability, technological change, innovation and sustainability, sustainable building design, environmental impact processes.

Broad fields as well as narrow groups compose the goal of EWG-ORSDCE.

\subsection{Achievements in books, postdoctoral and PhD theses publication}

The scientific achievements during the period from the 11th German-Lithuanian-Polish Colloquium until 12th German-Lithuanian-Polish Colloquium are presented in Table 1.

Table 1. Number of books, defended postdoctoral theses (Dr Sc) and Doctoral theses(PhD)

\begin{tabular}{l|c|c|c|c}
\hline \multirow{2}{*}{ Scientific results } & \multicolumn{3}{|c|}{ Year } & \multirow{2}{*}{ Total } \\
\cline { 2 - 4 } & 2007 & 2008 & 2009 & \\
\hline Number of books & 4 & 4 & 5 & 13 \\
\hline Number of Conferences Proceeding books & 3 & 2 & 3 & 8 \\
\hline Postdoctoral theses (Dr Sc) defended & 0 & 0 & 3 & 3 \\
\hline Doctoral theses defended (PhD) & 0 & 6 & 5 & 11 \\
\hline
\end{tabular}

As a result of these activities the monographs, manuals, etc. were published covering the following topics: the methods and models in engineering (Kapliński 2007); new construction, urban planning and utilities problems (Liias 2007a); multicriteria solution problem in construction (Zavadskas and Kaklauskas 2007); construction technology (Zavadskas et al. 2007e); fundamentals of enterprises management (Ginevičius and Silickas 2008); theory of organisation (Ginevičius and Sūdžius 2008); theory and practice of facilities management (Lepkova and Vilutienè 2008); technology of construction processes (Zavadskas et al. 2008i); information and intelligent technologies (Kaklauskas 2009); urban sustainability and governance (Kaklauskas 2009; Kaklauskas and HoltJensen 2009; Lepkova et al. 2009); construction organization (Zavadskas et al. 2009d); economics for the modern built environment (Ruddock 2009).

During 2007-2009 3 postdoctoral theses were defended. Postdoctoral thesis title of S. Mitkus (2009) (Lithuania) was "Modeling of Preparation of Construction Management Decisions Evaluating Law Environment of Construction" and thesis title of Z. Turskis (2009) (Lithuania) was "Multi-attribute assessment modeling of buildings' life cycle”. M. Nowak (2008) (Poland) defended his postdoctoral thesis „Interactive multicriteria decision aiding under risk: methods and applications".

During this period $\mathrm{PhD}$ theses were defended: 10 from Lithuania (Jakimavičius 2008; 
Keršulienė 2008; Mickaityte 2008; Naimavičienė 2008; Viteikienė 2008; Anikenienė 2009; Kalibatas 2009; Šliogerienė 2009; Tamošaitienė 2009; Urbanavičienė 2009) and 1 from Poland (Gajzler 2008b).

\subsection{Publication in journals and proceedings}

The research papers during 2007-2009 were published in 29 scientific journals in different research fields. The contribution of each country considering fields of research is presented in Fig. 3.

The published articles and proceedings during 2007-2009 are approximately 196 papers. Three papers in 2009-2010 were nominated by ScienceWatch.com. It has tracked the following papers which had the highest percentage increase in citations in Essential Science Indicators ${ }^{\mathrm{SM}}$ of Thomson Reuters (http://sciencewatch.com):

- In June 2009 as Fast Breaking Paper in the field of Economics \& Business the paper prepared by Turskis (2008) was selected;

- In January 2010 as New Hot Papers in the field of Economics \& Business the paper prepared by Ginevičius et al. (2008b) was selected and in the field of Engineering the paper prepared by Zavadskas et al. (2008f) was selected.

The authors of surveyed scientific publications are not necessarily the participants of these aforementioned colloquia but they actively work in achieving the goals of EWGORSDCE. These high achievements in publishing articles became the basis for the establishment of EWG-ORSDCE.

\subsection{Organization of International Conferences}

For the scientific activity during 2007-2009 7 international conferences were organized. The 5 of them were organized by Vilnius Gediminas Technical University (Zavadskas 2008f):

- the 9th International Conference „Modern building materials, structures and techniques" (May 16-18, 2007, Vilnius, Lithuania) (Skibniewski et al. 2007). On the basis of this conference special Issue of The Baltic Journal of Road and Bridge Engineering was published.

- the 11th Lithuanian-German-Polish Colloquium "Planning instruments in construction management" (October 23-25, 2007, Kolobrzeg, Poland) (Kapliński 2007, 2008d).

- the 20th International Conference, EURO Mini Conference "Continuous Optimization and Knowledge-Based Technologies” (EurOPT-2008) (May 20-23, 2008, Neringa, Lithuania). The Proceedings book (Sakalauskas et al. 2008) of selected papers as well as special issues in the journals Informatica (Dzemyda and Sakalauskas 2009) and Technological and Economic Development of Economy (Sakalauskas and Zavadskas 2009) have been published.

- the 25th International Symposium on Automation and Robotics in Construction ISARC-2008 (June 26-29, 2008, Vilnius, Lithuania). The Proceedings book of 


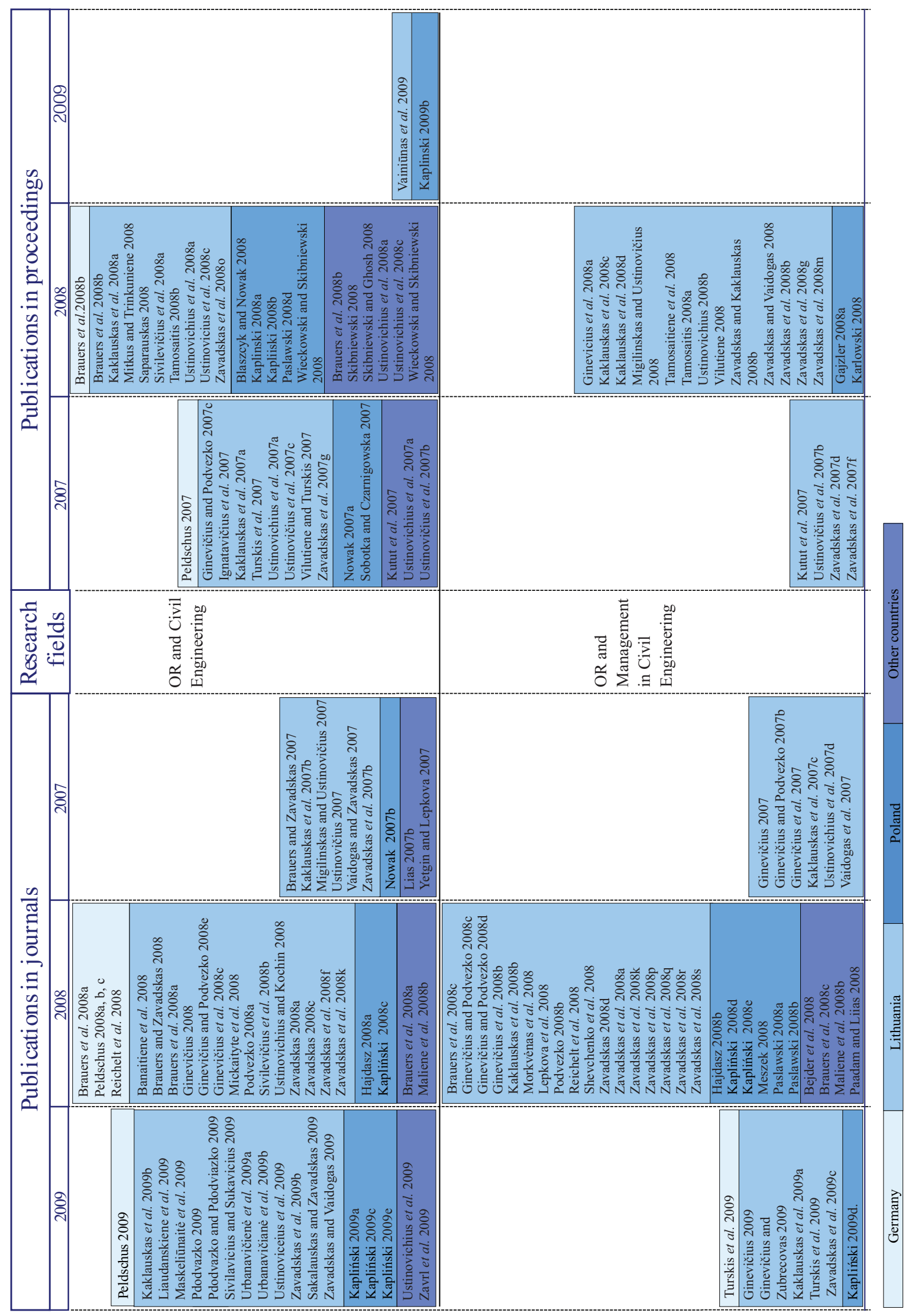



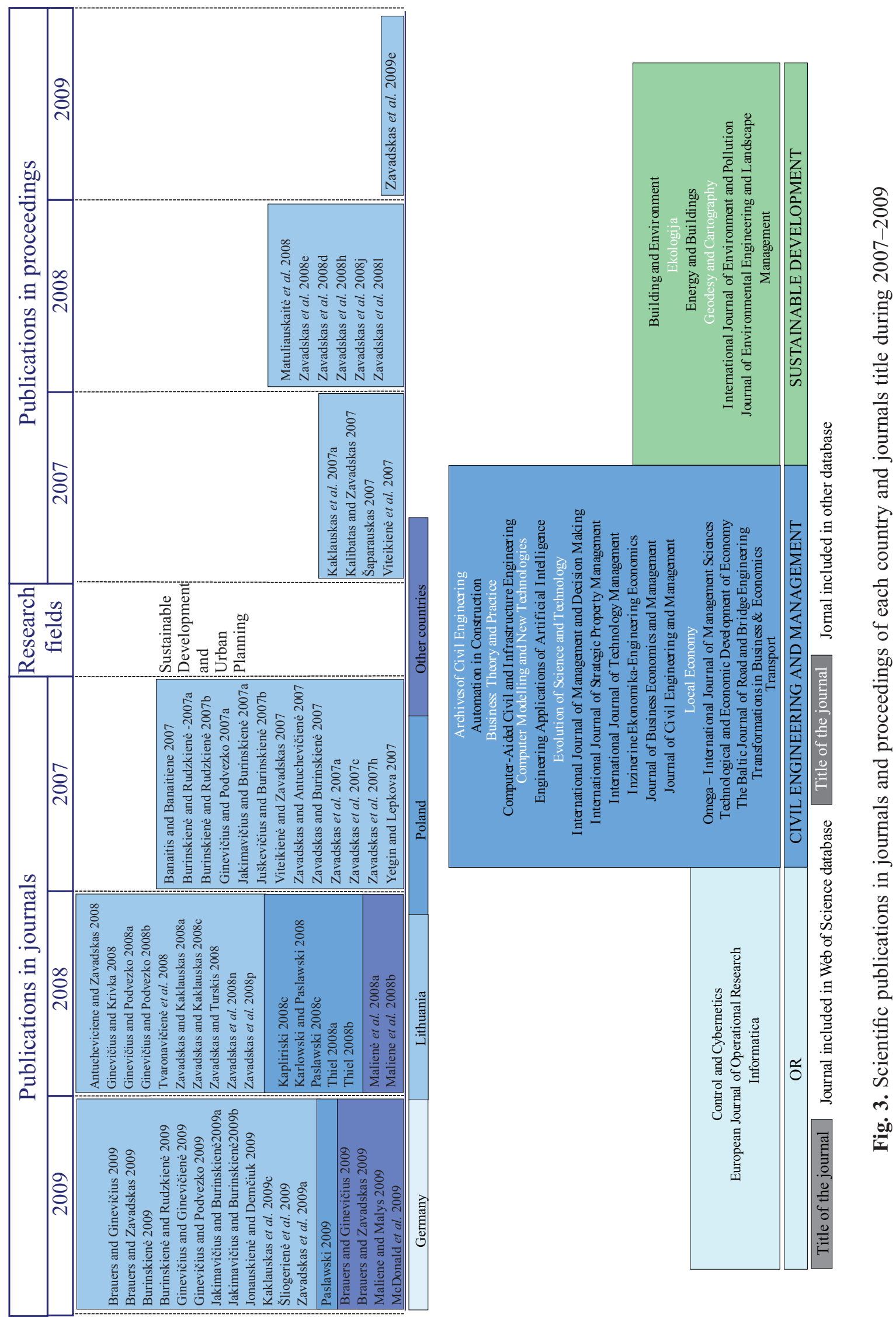
selected papers was published (Zavadskas et al. 2008c). The Special Issue of expanded papers on the basis of this Symposium has been published in scienfic journal Automation in Construction (Kaklauskas et al. 2010; Popov et al. 2010; Ustinovichius et al. 2010; Zavadskas 2010a, b).

- International Conference "Reliability and Statistics in Transportation and Communication" (RelStat'08) (October15-18, 2008, Riga, Latvia) (Kabashkin and Yatskiv 2008).

- the $13^{\text {th }}$ International Conference "Applied Stochastic Models and Data Analysis" ASMDA-2009 (June 30 - July 3, 2009, Vilnius, Lithuania). The Proceedings book has been published (Sakalauskas et al. 2009).

- the 5th International Conference EURO Mini Conference "Knowledge-Based Technologies and OR Methodologies for Strategic Decisions of Sustainable Development” KORSD-2009 (September 30 - October 3, 2009, Vilnius, Lithuania). Proceedings of selected papers have been published (Grasserbauer et al. 2009). In addition Special Issue of the Technological and Economic Development of Economy containing expanded versions of the selected papers will be published.

\section{Establishment of new EURO Working Group EWG-ORSDCE}

On the basis of the analysed wide range of topics during the 12th and the previous colloquiums and under the initiative of Prof. Edmundas Kazimieras Zavadskas the proposal to create EURO working group "OR in Sustainable Development and Civil Engineering (EWG-ORSDCE)" was prepared and presented to the participants of the $12^{\text {th }}$ German-Lithuanian-Polish colloquium. The scientists approved the proposal by their signatures and decided to submit this proposal to EURO (Association of European Operational Research Societies) Executive Committee during the annual 23rd European Conference on Operational Research „OR creating competitive advantage”, which took place in Bonn, Germany, 5-8 July 2009.

To the Board of EURO working group Prof. Edmundas Kazimieras Zavadskas, Prof. Leonidas Sakalauskas, Prof. Marija Burinskiene, Assoc. Prof. Tatjana Vilutiene (Vilnius Gediminas Technical University), Prof. Oleg Kaplinski (Poznan University of Technology), Prof. Friedel Peldschus (Leipzig University of Applied Sciences), Assoc. Prof. Jana Selih (University of Liubliana) and Dr Vida Maliene (Liverpool John Moores University) have been elected.

EURO committee during the EURO 23rd Conference in Bonn has discussed the proposal and approved the establishment of new working group under the sign of EURO. Currently the group joins 80 members from 19 countries (Lithuania, Germany, Poland, United Kingdom, Belgium, Denmark, Netherlands, Portugal, Latvia, Estonia, Czech Republic, Slovenia and Romania, Peru, Mexico, Russia, Ukraine, Australia and USA).

The scope of problems in research activities of the Working Group OR in Sustainable Development and Civil Engineering covers a wide range of rational decision-making problems within the field of sustainable development and civil engineering.

For more information regarding EWG-ORSDCE, its objectives, members, publications 
written in the field of Operational Research and activities of EURO Working Group OR in Sustainable Development and Civil Engineering (EWG-ORSDCE) visit the official website http://www.orsdce.vgtu.lt.

\section{Conclusions}

The achievements and scientific results of collaboration between German-LithuanianPolish scientific triangles give the next trend of OR and Civil Engineering science development including sustainability.

The collaboration which took almost 30 years resulted in significant achievements, which were accomplished by approximately 100 participants of this activity.

The main result of this activity was establishment of new EURO Working Group OR in Sustainable Development and Civil Engineering (EWG-ORSDCE).

\section{References}

Anikenienè, A. 2009. Research and modeling of the recent vertical movements on the earth's crust on the basis of geodetic measurements (samples on Lithuanian territory): summary of doctoral dissertation. Vilnius: Technika (in Lithuanian).

Antucheviciene, J.; Zavadskas, E. K. 2008. Modelling multidimensional redevelopment of derelict buildings, International Journal of Environment and Pollution 35(2/3/4): 331-344.

doi:10.1504/IJEP.2008.021364

Banaitis, A.; Banaitienè, N. 2007. Development of a rational housing model: the Lithuanian case, International Journal of Environment and Pollution 30(3/4): 430-442.

doi:10.1504/IJEP.2007.014820

Banaitiene, N.; Banaitis, A.; Kaklauskas, A.; Zavadskas, E. K. 2008. Evaluating the life cycle of a building: A multivariant and multiple criteria approach, Omega - International Journal of Management Sciences 36(3): 429-441. doi:10.1016/j.omega.2005.10.010

Bejder, E.; Wandahl, S.; Ebbesen, R. M. 2008. Future cooperation trends in the building industry, International Journal of Environment and Pollution 35(2/3/4): 296-308.

doi:10.1504/IJEP.2008.021362

Blaszczyk, T.; Nowak, M. 2008. Multiple-criteria interactive procedure in project management, in The 25th International Symposium on Automation and Robotics in Construction ISARC-2008: Selected papers, Ed. by E. Zavadskas, A. Kaklauskas, M. J. Skibniewski, June 26-29, 2008, Vilnius, Lithuania. Vilnius: Technika, 533-540. doi:10.3846/isarc.20080626.533

Brauers, W. K. M.; Ginevičius, R. 2009. Robustness in regional development studies. The case of Lithuania, Journal of Business Economics and Management 10(2): 121-140.

doi:10.3846/1611-1699.2009.10.121-140

Brauers, W. K. M.; Zavadskas, E. K. 2009. Robustness of the multi-objective MOORA method with a test for the facilities sector, Technological and Economic Development of Economy 15(2): 352-375. doi:10.3846/1392-8619.2009.15.352-375

Brauers, W. K. M.; Zavadskas, E. K. 2008. Multi-objective optimization in location theory with a simulation for a department store, Transformations in Business \& Economics 7(3): 163-183.

Brauers, W. K. M.; Zavadskas, E. K.; Peldschus, F.; Turskis, Z. 2008a. Multi-objective decisionmaking for road design, Transport 23(3): 183-193. doi:10.3846/1648-4142.2008.23.183-193

Brauers, W. K. M.; Zavadskas, E. K.; Peldschus, F.; Turskis, Z. 2008b. Multi-objective optimization of road design alternatives with an application of the MOORA method, in The 25th International 
Symposium on Automation and Robotics in Construction ISARC-2008: Selected papers. Ed. by E. Zavadskas, A. Kaklauskas, M. J. Skibniewski, June 26-29, 2008, Vilnius, Lithuania. Vilnius: Technika, 541-548. doi:10.3846/isarc.20080626.541

Brauers, W. K. M.; Zavadskas, E. K.; Turskis, Z.; Vilutienė, T. 2008c. Multi-objective contractor's ranking by applying the MOORA method, Journal of Business Economics and Management 9(4): 245-255. doi:10.3846/1611-1699.2008.9.245-255

Brauers, W. K. M.; Zavadskas, E. K. 2007. Editorial, Normalization in decision-making methods, International Journal of Management and Decision-Making 8(5/6): 441-444.

Burinskiene, M. 2009. New methodology for sustainable development towards sustainable transportation system, Technological and Economic Development of Economy 15(1): 5-9. doi:10.3846/1392-8619.2009.15.5-9

Burinskienè, M.; Rudzkienė, V. 2009. Future insights, scenarios and expert method application in sustainable territorial planning, Technological and Economic Development of Economy 15(1): 10-25. doi:10.3846/1392-8619.2009.15.10-25

Burinskienè, M.; Rudzkienè, V. 2007a. Application of logit regression models for the identification of market segments, Journal of Business Economics and Management 8(4): 253-258.

Burinskienè, M.; Rudzkienė, V. 2007b. Variability and the relationship between quality of life and real estate prices in Lithuania, International Journal of Environment and Pollution 30(3/4): 501-517. doi:10.1504/IJEP.2007.014825

Dzemyda, G.; Sakalauskas, L. 2009. Optimization and Knowledge-Based Technologies, Informatica 20(2): $165-172$.

Gajzler, M. 2008a. Hybrid advisory system and the possibilities of its usage in the process of industrial flooring repairs, in The 25th International Symposium on Automation and Robotics in Construction ISARC-2008: Selected papers. Ed. by E. Zavadskas, A. Kaklauskas, M. J. Skibniewski, June 26-29, 2008, Vilnius, Lithuania. Vilnius: Technika, 459-464.

doi:10.3846/isarc.20080626.459

Gajzler, M. 2008b. Hybrid advisory system for industrial concrete floors repairs of publishing office: doctoral dissertation. Poznan University of Technology, Faculty of Civil and Environmental Engineering.

Ginevičius, R. 2009. Some problems of quantitative evaluation of the state of social-economic systems, Verslas: teorija ir praktika [Business: Theory and Practice] 10(2): 69-83.

doi:10.3846/1648-0627.2009.10.69-83

Ginevičius, R. 2008. Normalization of quantities of various dimensions, Journal of Business Economics and Management 9(1): 79-86. doi:10.3846/1611-1699.2008.9.79-86

Ginevičius, R. 2007. Hierarchical structuring of processes and phenomena, Verslas: teorija ir praktika [Business: Theory and Practice] 8(1): 14-18.

Ginevičius, R.; Ginevičienè, V. B. 2009. The compliance of master's degree studies with the economic needs of the country, Technological and Economic Development of Economy 15(1): 136-153. doi:10.3846/1392-8619.2009.15.136-153

Ginevičius, R.; Krivka, A. 2008. Application of game theory for duopoly market analysis, Journal of Business Economics and Management 9(3): 207-217. doi:10.3846/1611-1699.2008.9.207-217

Ginevičius, R.; Podvezko, V. 2009. Evaluating the changes in economic and social development of Lithuanian counties by multiple criteria methods, Technological and Economic Development of Economy 15(3): 418-436. doi:10.3846/1392-8619.2009.15.418-436

Ginevičius, R.; Podvezko, V. 2008a. A feasibility study of multicriteria methods' application to quantitative evaluation of social phenomena, Verslas: teorija ir praktika [Business: Theory and Practice] 9(2): 81-87. doi:10.3846/1648-0627.2008.9.81-87

Ginevičius, R.; Podvezko, V. 2008b. Housing in the context of economic and social development 
of Lithuanian regions, International Journal of Environment and Pollution 35(2/3/4): 309-330. doi:10.1504/IJEP.2008.021363

Ginevičius, R.; Podvezko, V. 2008c. Multicriteria evaluation of Lithuanian banks from the perspective of their reliability for clients, Journal of Business Economics and Management 9(4): 257-267. doi:10.3846/1611-1699.2008.9.257-267

Ginevičius, R.; Podvezko, V. 2008d. Multicriteria graphical-analytical evaluation of the financial state of construction enterprises, Technological and Economic Development of Economy 14(4): 452-461. doi:10.3846/1392-8619.2008.14.452-461

Ginevičius, R.; Podvezko, V. 2008e. The problem of compatibility of various multiple criteria evaluation methods, Verslas: teorija ir praktika [Business: Theory and Practice] 9(1): 73-80. doi:10.3846/1648-0627.2008.9.73-80

Ginevičius, R.; Podvezko, V. 2007a. Complex assessment of sustainable development of state regions with emphasis on ecological and dwelling conditions, Ekologija 53(Suppl.): 41-48.

Ginevičius, R.; Podvezko, V. 2007b. Some problems of evaluating multicriteria decision methods, International Journal of Management and Decision Making 8(5/6): 527-539. doi:10.1504/IJMDM.2007.013415

Ginevičius, R.; Podvezko, V. 2007c. The influence of complex evaluation methods on rating the alternative operations of wall insulation, in The 9th International Conference "Modern Building Materials, Structures and Techniques”. Vol. 1-3. Ed. by M. J. Skibniewski; P. Vainiunas, E. K. Zavadskas, May 16-18, 2007, Vilnius, Lithuania. Vilnius:Technika, 248-251.

Ginevičius, R.; Silickas, J. 2008. Sisteminio i̇moniu valdymo pagrindai. Vilnius: Technika (in Lithuanian). doi:10.3846/1000-S

Ginevičius, R.; Sūdžius, V. 2008. Organizaciju teorija. 2nd ed. Vilnius: Technika (in Lithuanian). doi:10.3846/934-S

Ginevičius, R.; Zubrecovas, V. 2009. Selection of the optimal real estate investment project basing on multiple criteria evaluation using stochastic dimensions, Journal of Business Economics and Management 10(3): 261-270. doi:10.3846/1611-1699.2009.10.261-270

Ginevicius, R.; Podvezko, V.; Andruskevicius, A. 2008a. The effectiveness of diversification of construction enterprise activities, in The 25th International Symposium on Automation and Robotics in Construction ISARC-2008: Selected papers, Ed. by E. Zavadskas, A. Kaklauskas, M. J. Skibniewski, June 26-29, 2008, Vilnius, Lithuania. Vilnius: Technika, 759-763.

doi:10.3846/isarc.20080626.759

Ginevičius, R.; Podvezko, V.; Bruzgè, Š. 2008b. Evaluating the effect of state aid to business by multicriteria methods, Journal of Business Economics and Management 9(3): 167-180.

doi:10.3846/1611-1699.2008.9.167-180

Ginevičius, R.; Podvezko, V.; Raslanas, S. 2008c. Evaluating the alternative solutions of wall insulation by multicriteria methods, Journal of Civil Engineering and Management 14(4): 217-226. doi:10.3846/1392-3730.2008.14.20

Ginevičius, R.; Podvezko, V.; Andruškevičius, A. 2007. Quantitative evaluation of building technology, International Journal of Technology Management 40(1/2/3): 192-214.

Grasserbauer, M.; Sakalauskas, L.; Zavadskas, E. K. (Eds.). 2009. The 5th International Vilnius Conference EURO-Mini Conference "Knowledge - based Technologies and OR Methodologies for Strategic Decisions of Sustainable Development (KORSD-2009) “. September 30 - October 3, 2009, Vilnius, Lithuania, Vilnius: Technika. 549 p. ISBN 978-9955-28-482-6.

Hajdasz, M. 2008a. Modelling and simulation of monolithic construction processes, Technological and Economic Development of Economy 14(4): 478-491. doi:10.3846/1392-8619.2008.14.478-491

Hajdasz, M. 2008b. Visualizing simulated monolithic construction processes, Journal of Civil Engineering and Management 14(4): 295-306. doi:10.3846/1392-3730.2008.14.29 
Ignatavičius, Č.; Zavadskas, E. K.; Ustinovičius, L. 2007. Renovation of large-panel houses in Vilnius, in The 9th International Conference "Modern Building Materials, Structures and Techniques". Vol. 1-3. Ed. by M. J. Skibniewski; P. Vainiunas, E. K. Zavadskas, May 16-18, 2007, Vilnius, Lithuania. Vilnius: Technika, 258-264.

Jakimavičius, M. 2008. Multi-criteria assessment of urban areas transport system development according to sustainability: doctoral dissertation. Vilnius: Technika.

Jakimavičius, M.; Burinskienè, M. 2009a. A GIS and multi-criteria-based analysis and ranking of transportation zones of Vilnius city, Technological and Economic Development of Economy 15(1): 39-48. doi:10.3846/1392-8619.2009.15.39-48

Jakimavičius, M.; Burinskienè, M. 2009b. Assessment of Vilnius city development scenarios based on transport system modelling and multicriteria analysis, Journal of Civil Engineering and Management 15(4): 361-368. doi:10.3846/1392-3730.2009.15.361-368

Jakimavičius, M.; Burinskienė, M. 2007a. Automobile transport system analysis and ranking in Lithuanian administrative regions, Transport 22(3): 214-220.

Juškevičius, P.; Burinskiene, M. 2007b. Quality factors of the residential environment in urban planning, International Journal of Environment and Pollution 30(3/4): 471-484.

doi:10.1504/IJEP.2007.014823

Jonauskienè, I.; Demčiuk, S. 2009. The application of multi-criteria analysis to quality assessment of land parcels cadastral data, Geodesy and Cartography 35(2): 66-71.

Kabashkin, I. V.; Yatskiv, J. (Eds.). 2008. The $8^{\text {th }}$ International Conference "Reliability and Statistics in Transportation and Communication" (RelStat '08). October 15-18, 2008, Riga, Latvia. Transport and Telecommunication Institute. 375 p. ISBN 978-9984-818-11-5

Kaklauskas, A.; Zavadskas, E. K.; Naimavičienè, J.; Krutinis, M.; Plakys, V.; Venskus, D. 2010. Model for a complex analysis of intelligent built environment, Automation in Construction 19: 326-340. doi:10.1016/j.autcon.2009.12.006

Kaklauskas, A. 2009. Information and intelligent technologies for neighbourhoods: Appendix 2, in A. Holt-Jensen, E. Pollock (Eds.). Urban sustainability and governance: new challenges in NordicBaltic housing policies. New York : Nova Science Publishers, 305-321.

Kaklauskas, A.; Holt-Jensen, A. 2009. Ghettos and enclaves as including and excluding neighbourhoods, in A. Holt-Jensen, E. Pollock (Eds.). Urban sustainability and governance: new challenges in Nordic-Baltic housing policies. New York : Nova Science Publishers, 227-229.

Kaklauskas, A.; Zavadskas, E. K.; Budzevičienè, R. 2009a. Web-based model of multiple criteria ethical decision-making for ethical behaviour of students, Journal of Business Economics and Management 10(1): 71-84. doi:10.3846/1611-1699.2009.10.71-84

Kaklauskas, A.; Zavadskas, E.; Raslanas, S. 2009b. Modelling and simulation of real estate sector: the Case of Lithuania, Transformations in Business and Economics 8(1): 101-120.

Kaklauskas, A.; Zavadskas, E. K.; Šaparauskas, J. 2009c. Conceptual modelling of sustainable Vilnius development, Technological and Economic Development of Economy 15(1): 154-177. doi:10.3846/1392-8619.2009.15.154-177

Kaklauskas, A.; Kersuliene, V.; Urbanaviciene, V. 2008a. Determination of rational method for resolution of disputes with the help of multi-criteria negotiation decision support system for real estate, in The 25th International Symposium on Automation and Robotics in Construction ISARC-2008: Selected papers. Ed. by E. Zavadskas, A. Kaklauskas, M. J. Skibniewski, June 26-29, 2008, Vilnius, Lithuania. Vilnius: Technika, 585-591. doi:10.3846/isarc.20080626.585

Kaklauskas, A.; Zavadskas, E. K.; Galiniene, B. 2008b. A building's refurbishment knowledge-based decision support system, International Journal of Environment and Pollution 35(2/3/4): 237-249. doi:10.1504/IJEP.2008.021358

Kaklauskas, A.; Zavadskas, E. K.; Seniut, M.; Krutinis, M.; Dzemyda, G.; Ivanikovas, S.; Stankevic, V.; 
Simkevicius, C.; Jarusevicius, A. 2008c. Web-based biometric mouse decision support system for user's emotional and labour productivity analysis, in The 25th International Symposium on Automation and Robotics in Construction ISARC-2008: Selected papers. Ed. by E. Zavadskas, A. Kaklauskas, M. J. Skibniewski, June 26-29, 2008, Vilnius, Lithuania. Vilnius: Technika, 69-75. doi:10.3846/isarc.20080626.69

Kaklauskas, A.; Zavadskas, E. K.; Trinkunas, V. 2008d. Model for an integrated analysis of distance learning quality: The case of Lithuania, in The 25th International Symposium on Automation and Robotics in Construction ISARC-2008: Selected papers. Ed. by E. Zavadskas, A. Kaklauskas, M. J. Skibniewski, June 26-29, 2008. Vilnius, Lithuania. Vilnius: Technika, 849-853. doi:10.3846/isarc.20080626.849

Kaklauskas, A.; Naimavičienė, J.; Tupėnaitè, L.; Kanapeckienė, L. 2007a. Knowledge- based model for sustainable housing renovation, in The 9th International Conference "Modern Building Materials, Structures and Techniques”. Vol. 1-3. Ed. by M. J. Skibniewski; P. Vainiunas, E. K. Zavadskas, May 16-18, 2007. Vilnius, Lithuania. Vilnius: Technika, 276-281.

Kaklauskas, A.; Zavadskas, E. K.; Banaitis, A.; Šatkauskas, G. 2007b. Defining the utility and market value of a real estate: a multiple criteria approach, International Journal of Strategic Property Management 11(2): 107-120.

Kaklauskas, A.; Zavadskas, E. K.; Trinkūnas, V. 2007c. A multiple criteria decision support on-line system for construction, Engineering Applications of Artificial Intelligence 20(2):163-175. doi:10.1016/j. engappai.2006.06.009

Kalibatas, D. 2009. The multi-attribute assessment of environmental factors influencing on dwellinghouses: summary of doctoral dissertation. Vilnius: Technika.

Kalibatas, D.; Zavadskas, E. K. 2007. Multiple criteria analysis of indoor climate at the workplace, in The 9th International Conference "Modern Building Materials, Structures and Techniques". Vol. 1-3. Ed. by M. J. Skibniewski; P. Vainiunas, E. K. Zavadskas, May 16-18, 2007. Vilnius, Lithuania. Vilnius: Technika, 282-286.

Kapliński, O. 2010. Review of trans-border cooperation in construction management between Lithuania, Germany and Poland, Evolution of Science and Technology (in Press).

Kapliński, O. 2009a. Sapere Aude: Professor Edmundas Kazimieras Zavadskas, Inzinerine Ekonomi$k a$-Engineering Economics (5): 113-119.

Kapliński, O. 2009b. Discrepancy in the assessment of attractiveness and usefulness of IT and planning methods by businessmen and academics, in Proc. 5th Nordic Conference on Construction Economics and Organization, vol. 1. June 10-12, 2009. Reykjavik, Iceland, 145-154. ISBN 978-9979-9483-9-1

Kapliński, O. 2009c. Information technology in the development of the Polish construction industry, Technological and Economic Development of Economy 15(3): 437-452.

doi:10.3846/1392-8619.2009.15.437-452

Kapliński, O. 2009d. Problems of information technologies use in Polish construction sector: state of the art, Archives of Civil Engineering 55(2): 173-198.

Kapliński, O. 2009e. Professor Edmundas Kazimieras Zavadskas: the research achievements and transborder cooperation, Archives of Civil Engineering 55(3): 287-300.

Kaplinski, O. 2008a. IT applications in Polish construction sector, in The 25th International Symposium on Automation and Robotics in Construction ISARC-2008: Selected papers. Ed. by E. Zavadskas, A. Kaklauskas, M. J. Skibniewski, June 26-29, 2008, Vilnius, Lithuania. Vilnius: Technika, 483-489. doi:10.3846/isarc.20080626.483

Kapliński, O. 2008b. Advancement in construction management tools: the Polish experience, in Proc. of $2^{\text {nd }}$ International Conference on Advances in Concrete and Construction (ICACC-2008). Ed. by P. Jagannadha Rao, V. Ramakrishnan, I. Patnaikuni, V. S. Parameswaran, 7-9 February 2008, Hyderabad, India, 7-9. 
Kapliński, O. 2008c. Development and usefulness of planning techniques and decision making foundations on the example of construction enterprises in Poland, Technological and Economic Development of Economy 14(4): 492-502. doi:10.3846/1392-8619.2008.14.492-502

Kapliński, O. 2008d. Planning instruments in construction management, Technological and Economic Development of Economy 14(4): 449-451. doi:10.3846/1392-8619.2008.14.449-451

Kapliński, O. 2008e. Usefulness and credibility of scoring methods in construction industry, Journal of Civil Engineering and Management 14(1): 21-28. doi:10.3846/1392-3730.2008.14.21-28

Kapliński, O. (Ed.). 2007. Metody i modele badań w inżynierii przedsięwzięć budowlanych [Methods and models of research in construction project engineering]. PAN, KILiW, IPPT, Seria: Studia z Zakresu Inżynierii Nr. 57. Warszawa (in Polish).

Karlowski, A. 2008. Telemetric system for management in concrete process, in The 25th International Symposium on Automation and Robotics in Construction ISARC-2008: Selected papers. Ed. by E. Zavadskas, A. Kaklauskas, M. J. Skibniewski, June 26-29, 2008. Vilnius, Lithuania. Vilnius: Technika, 318-323. doi:10.3846/isarc.20080626.318

Karlowski, A.; Paslawski, J. 2008. Monitoring of construction processes in the variable environment, Technological and Economic Development of Economy 14(4): 503-517.

doi:10.3846/1392-8619.2008.14.503-517

Keršuliene, V. 2008. Determination of the rational method of solutions in disputes between the contractor and client based on the theory: summary of doctoral dissertation. Vilnius: Technika.

Kutut, V.; Ustinovichius, L.; Kochin, D.; Turskis, Z. 2007. Verbal analysis as an effective tool of investment strategy management, in The 9th International Conference "Modern Building Materials, Structures and Techniques”. Vol. 1-3. Ed. by M. J. Skibniewski; P. Vainiunas, E. K. Zavadskas, May 16-18, 2007. Vilnius, Lithuania. Vilnius:Technika, 293-299.

Lepkova, N.; Vilutienè, T. 2008. Facilities management: theory and practice. Vilnius: Technika (in Lithuanian).

Lepkova, N.; Mickaitytė, A.; Standl, H.; Krupickaite, D.; Kaklauskas, A. 2009. Housing trends in Lithuania, in A. Holt-Jensen, E. Pollock (Eds.). Urban Sustainability and Governance: new Challenges in Nordic-Baltic Housing Policies. New York: Nova Science Publishers, 209-225.

Lepkova, N.; Kaklauskas, A.; Zavadskas, E. K. 2008. Modelling of facilities management alternatives, International Journal of Environment and Pollution 35(2/3/4): 185-204. doi:10.1504/IJEP.2008.021355

Liias, R. 2007a. Existing housing situation, new construction, urban planning and utilities. United Nations Economic Commission for Europe, Country Profiles on the Housing Sector (21-31). Switzerland, Geneva, United Nations.

Liias, R. 2007b. Housing maintenance management: the key-factor when creating healthy environment, International Journal of Environment and Pollution 30(3/4): 457-470.

doi:10.1504/IJEP.2007.014822

Liaudanskiene, R.; Ustinovicius, L.; Bogdanovicius, A. 2009. Valuation of construction process safety solutions using the TOPSIS method, Inzinerine Ekonomika - Engineering Economics (4): 32-40.

Maliene, V.; Malys, N. 2009. High-quality housing - a key issue in delivering sustainable communities, Building and Environment 44(2): 426-430. doi:10.1016/j.buildenv.2008.04.004

Malienè, V.; Howe, J.; Malys, N. 2008a. Sustainable communities: Affordable housing and socioeconomic relations, Local Economy 23: 267-276. doi:10.1080/02690940802407989

Maliene, V.; Alexander, K.; Lepkova, N. 2008b. Facilities management development in Europe, International Journal of Environment and Pollution 35(2/3/4): 171-184.

doi:10.1504/IJEP.2008.021354

Maskeliūnaitè, L.; Sivilevičius, H.; Podvezko, V. 2009. Research on the quality of passenger transpor- 
tation by railway, Transport 24(2): 100-112. doi:10.3846/1648-4142.2009.24.100-112

Matuliauskaite, A.; Vetaite, V.; Kaklauskas, A. 2008. Assessment of air pollution PM10 in the city of Vilnius and its influence on life quality, in The 25th International Symposium on Automation and Robotics in Construction ISARC-2008: Selected papers. Ed. by E. Zavadskas, A. Kaklauskas, M. J. Skibniewski, June 26-29, 2008, Vilnius, Lithuania. Vilnius: Technika, 782-788.

doi:10.3846/isarc.20080626.782

McDonald, S.; Malys, N.; Malienė, V. 2009. Urban regeneration for sustainable communities : a case study, Technological and Economic Development of Economy 15(1): 49-59.

doi:10.3846/1392-8619.2009.15.49-59

Meszek, W. 2008. The analysis of property value increase as a result of infrastructural investment projects, International Journal of Environment and Pollution 35(2/3/4): 345-365.

doi:10.1504/IJEP.2008.021365

Mickaityte, A. 2008. Refurbishment of public buildings according to sustainability principles: summary of doctoral dissertation. Vilnius: Technika.

Mickaityte, A.; Zavadskas, E. K.; Kaklauskas, A.; Tupenaitè, L. 2008. The concept model of sustainable buildings refurbishment, International Journal of Strategic Property Management 12(1): 53-68. doi:10.3846/1648-715X.2008.12.53-68

Migilinskas, D.; Ustinovicius, L. 2008. Methodology of risk and uncertainty management in construction's technological and economical problems, in The 25th International Symposium on Automation and Robotics in Construction ISARC-2008: Selected papers. Ed. by E. Zavadskas, A. Kaklauskas, M. J. Skibniewski, June 26-29, 2008, Vilnius, Lithuania. Vilnius: Technika, 789-795.

doi:10.3846/isarc.20080626.789

Migilinskas, D.; Ustinovičius, L. 2007. Normalisation in the selection of construction alternatives, International Journal of Management and Decision Making 8(5/6): 623-639. doi:10.1504/IJMDM.2007.013422

Mitkus, S. 2009. Modeling of Preparation of Construction Management Decisions Evaluating Law Environment of Construction: postdoctoral thesis. Vilnius: Technika (in Lithuanian).

Mitkus, S.; Trinkuniene, E. 2008. Decision support in analysis of construction contracts, in The 25th International Symposium on Automation and Robotics in Construction ISARC-2008: Selected papers. Ed. by E. Zavadskas, A. Kaklauskas, M. J. Skibniewski, June 26-29, 2008, Vilnius, Lithuania. Vilnius: Technika, 604-609. doi:10.3846/isarc.20080626.604

Morkvėnas, R.; Bivainis, J.; Jaržemskis, A. 2008. Assessment of employee's knowledge potential in transport sector, Transport 23(3): 258-265. doi:10.3846/1648-4142.2008.23.258-265

Naimavičienè, J. 2008. Intelligent knowledge and device-based assisted residential environment: summary of doctoral dissertation. Vilnius: Technika.

Nowak, M. 2008. Interactive multicriteria decision aiding under risk. Methods and application. Post Doctoral thesis. Karol Adamiecki University of Economics Press, Katowice (in Polish).

Nowak, M. 2007a. Aggregate production planning with simulations and multicriteria interactive procedure, in The 9th International Conference "Modern Building Materials, Structures and Techniques". Vol. 1-3. Ed. by M. J. Skibniewski, P. Vainiunas, E. K. Zavadskas, May 16-18, 2007, Vilnius, Lithuania. Vilnius: Technika, 323-328.

Nowak, M. 2007b. Aspiration level approach in stochastic MCDM problems, European Journal of Operational Research 177(3): 1626-1640. doi:10.1016/j.ejor.2005.10.003

Paadam, K.; Liias, R. 2008. Knowledgeability and capacity of the owners: assuring professionalism when providing housing services, International Journal of Environment and Pollution 35(2/3/4): 205-218. doi:10.1504/IJEP.2008.021356

Paslawski, J. 2009. Flexibility in highway noise management, Transport 24(1): 66-75.

doi:10.3846/1648-4142.2009.24.66-75 
Paslawski, J. 2008a. Flexibility approach in construction process engineering, Technological and Economic Development of Economy 14(4): 518-530. doi:10.3846/1392-8619.2008.14.518-530

Paslawski, J. 2008b. Flexibility approach in the runway pavement using FLEMANCO method, Transport 23(4): 341-350. doi:10.3846/1648-4142.2008.23.341-350

Paslawski, J. 2008c. Highway noise management using advisory system, International Journal of Environment and Pollution 35(2/3/4): 275-295. doi:10.1504/IJEP.2008.021361

Paslawski, J. 2008d. Flexibility implementation in construction process engineering, in The 25th International Symposium on Automation and Robotics in Construction ISARC-2008: Selected papers. Ed. by E. Zavadskas, A. Kaklauskas, M. J. Skibniewski, June 26-29, 2008, Vilnius, Lithuania. Vilnius: Technika, 610-615. doi:10.3846/isarc.20080626.610

Peldschus, F. 2009. The analysis of the quality of the results obtained with the methods of multi-criteria decisions, Technological and Economic Development of Economy 15(4): 580-592.

doi:10.3846/1392-8619.2009.15.580-592

Peldschus, F. 2008a. Experience of the game theory application in construction management, Technological and Economic Development of Economy 14(4): 531-545.

doi:10.3846/1392-8619.2008.14.531-545

Peldschus, F. 2008b. Multi-attribute decisions in construction, Transformations in Business \& Economics 7(2): 163-165.

Peldschus, F. 2008c. Mehrzielselektion für Entscheidungen im Bauwesen, Journal of Civil Engineering and Management 14(2): II.

Peldschus, F. 2007. Game-theory solutions in construction operation, in The 9th International Conference "Modern Building Materials, Structures and Techniques". Vol. 1-3. Ed. by M. J. Skibniewski; P. Vainiunas, E. K. Zavadskas, May 16-18, 2007, Vilnius, Lithuania. Vilnius: Technika, 348-353.

Podvezko, V. 2009. Application of AHP technique, Journal of Business Economics and Management 10(2): 181-189. doi:10.3846/1611-1699.2009.10.181-189

Podvezko, V. 2008a. Book review game theory in building technology and management, Journal of Business Economics and Management 9(3): 237-239. doi:10.3846/1611-1699.2008.9.237-239

Podvezko, V. 2008b. Comprehensive evaluation of complex quantities, Verslas:teorija ir praktika [Business: Theory and Practice] 9(3): 160-168. doi:10.3846/1648-0627.2008.9.160-168

Podvezko, V.; Podviezko, A. 2009. PROMETHEE I method application for identification of the best alternative, Verslas:teorija ir praktika, [Business: Theory and Practice] 10(2): 84-92.

doi:10.3846/1648-0627.2009.10.84-92

Popov, V.; Juocevicius, V.; Migilinskas, D.; Ustinovichius, L.; Mikalauskas, S. 2010. The use of a virtual building design and construction model for developing an effective project concept in 5D environment, Automation in Construction 19(3): 357-367. doi:10.1016/j.autcon.2009.12.005

Reichelt, B.; Melnikas, B.; Vilutiene, T. 2008. The model for selection of a maintenance strategy for municipal buildings, International Journal of Environment and Pollution 35(2/3/4): 219-236. doi:10.1504/IJEP.2008.021357

Ruddock, L. (Ed.). 2009. Economics for the modern built environment. Taylor \& Francis.

Sakalauskas, L.; Zavadskas, E. K. 2009. Optimization and intelligent decisions, Technological and Economic Development of Economy 15(2): 189-196. doi:10.3846/1392-8619.2009.15.189-196

Sakalauskas, L.; Skiadas, C.; Zavadskas, E. K. (Eds.). 2009. The 13th International Conference "Applied Stochastic Models and Data Analysis" ASMDA-2009. Selected papers. June 30 - July 3, 2009, Vilnius, Lithuania. Vilnius: Technika. 535 p. ISBN 978-9955-28-463-5

Sakalauskas, L.; Weber, G. W.; Zavadskas, E. K. (Eds.). 2008. The 20th International Conference EURO Mini Conference "Continuous Optimization and Knowledge-Based Technologies" (EurOPT 2008). Selected papers. May 20-23, 2008, Neringa, Lithuania. Vilnius: Technika. 490 p.

ISBN 978-9955-28-283-9 
Saparauskas, J. 2008. Automated evaluation of alternative solutions of building design, in The 25th International Symposium on Automation and Robotics in Construction ISARC-2008: Selected papers. Ed. by E. Zavadskas, A. Kaklauskas, M. J. Skibniewski, June 26-29, 2008, Vilnius, Lithuania. Vilnius: Technika, 656-663. doi:10.3846/isarc.20080626.656

Shevchenko, G.; Ustinovichius, L.; Andruškevičius, A. 2008. Multi-attribute analysis of investments risk alternatives in construction, Technological and Economic Development of Economy 14(3): 428443. doi:10.3846/1392-8619.2008.14.428-443

Sivilevicius, H.; Sukevicius, S. 2009. Manufacturing technologies and dynamics of hot-mix asphalt Mixture Production, Journal of Civil Engineering and Management 15(2): 169-179.

doi:10.3846/1392-3730.2009.15.169-179

Sivilevicius, H.; Zavadskas, E. K.; Turskis, Z. 2008a. Multi-attribute assessment of the asphalt mixing plants, in The 25th International Symposium on Automation and Robotics in Construction ISARC-2008: Selected papers. Ed. by E. Zavadskas, A. Kaklauskas, M. J. Skibniewski, June 26-29, 2008, Vilnius, Lithuania. Vilnius: Technika, 717-729. doi:10.3846/isarc.20080626.717

Sivilevičius, H.; Zavadskas, E. K.; Turskis, Z. 2008b. Quality attributes and complex assessment methodology of the asphalt mixing plant, The Baltic Journal of Road and Bridge Engineering 3(3): 101-166.

Skibniewski, M. J. 2008. Optimal buildings through automation technology: toward systems unification for secure, intelligent, green, and immune buildings, in The 25th International Symposium on Automation and Robotics in Construction ISARC-2008: Selected papers. Ed. by E. Zavadskas, A. Kaklauskas, M. J. Skibniewski, June 26-29, 2008, Vilnius, Lithuania. Vilnius: Technika, 1-4. doi:10.3846/isarc.20080626.1

Skibniewski, M. J.; Ghosh, S. 2008. Identifying elements of enterprise wide application selection eco-system, in The 25th International Symposium on Automation and Robotics in Construction ISARC-2008: Selected papers. Ed. by E. Zavadskas, A. Kaklauskas, M. J. Skibniewski, June 26-29, 2008, Vilnius, Lithuania. Vilnius: Technika, 810-816. doi:10.3846/isarc.20080626.810

Skibniewski, M. J.; Vainiūnas, P.; Zavadskas, E. K. (Eds.). 2007. The 9th International Conference "Modern Buildings, Materials, Structures and Techniques". Selected Papers, Vol. 1-3. May 16-18, 2007, Vilnius. Vilnius: Technika. 1226 p. ISBN 978-9955-28-201-3

Sobotka, A.; Czarnigowska, A. 2007. Target costing in public construction projects, in The 9th International Conference "Modern Building Materials, Structures and Techniques". Vol. 1-3. Ed. by M. J. Skibniewski; P. Vainiunas, E. K. Zavadskas, May 16-18, 2007. Vilnius, Lithuania. Vilnius: Technika, 375-380.

Šaparauskas, J. 2007. The main aspects of sustainability evaluation in construction, in The 9th International Conference "Modern Building Materials, Structures and Techniques". Vol. 1-3. Ed. by M. J. Skibniewski, P. Vainiunas, E. K. Zavadskas, May 16-18, 2007, Vilnius, Lithuania. Vilnius: Technika, 365-370.

Šelih, J.; Kne, A.; Srdić, A.; Žura, M. 2008. Multiple-criteria decision support system in highway infrastructure management, Transport 23(4): 299-305. doi:10.3846/1648-4142.2008.23.299-305

Šliogerienè, J. 2009. Property valuation in energy companies: summary of doctoral dissertation. Vilnius: Technika.

Šliogerienė, J.; Kaklauskas, A.; Zavadskas, E. K.; Bivainis, J.; Seniut, M. 2009. Environment factors of energy companies and their effect on value: analysis model and applied method, Technological and Economic Development of Economy 15(3): 490-521. doi:10.3846/1392-8619.2009.15.490-521

Tamošaitienè, J. 2009. The multi-attribute assessment of management decisions at the stage of construction planning: summary of doctoral dissertation. Vilnius: Technika.

Tamosaitiene, J.; Turskis, Z.; Zavadskas, E. K. 2008. Modeling of contractor selection taking into account different risk level, in The 25th International Symposium on Automation and Robotics in Construction ISARC-2008: Selected papers. Ed. by E. Zavadskas, A. Kaklauskas, M. J. Skibniewski, 
June 26-29, 2008, Vilnius, Lithuania. Vilnius: Technika, 676-681. doi:10.3846/isarc.20080626.676

Tamosaitis, R. 2008a. Simulation of technological processes using knowledge-based sequences, in The 25th International Symposium on Automation and Robotics in Construction ISARC-2008: Selected papers. Ed. by E. Zavadskas, A. Kaklauskas, M. J. Skibniewski, June 26-29, 2008, Vilnius, Lithuania. Vilnius: Technika, 670-675. doi:10.3846/isarc.20080626.670

Tamosaitis, R. 2008b. Automated standard work time development in construction, in The 25th International Symposium on Automation and Robotics in Construction ISARC-2008: Selected papers. Ed. by E. Zavadskas, A. Kaklauskas, M. J. Skibniewski, June 26-29, 2008, Vilnius, Lithuania. Vilnius: Technika, 664-669. doi:10.3846/isarc.20080626.664

Thiel, T. 2008a. Decision aiding related to maintenance of buildings: technical, economic and environmental aspects, International Journal of Environment and Pollution 35(2/3/4): 158-170. doi:10.1504/IJEP.2008.021353

Thiel, T. 2008b. Determination of the relative importance of criteria when the number of people judging is a small sample, Technological and Economic Development of Economy 14(4): 566-577. doi:10.3846/1392-8619.2008.14.566-577

Turskis, Z. 2009. Multi-attribute assessment modelling of buildings' life cycle: postdoctoral thesis. Vilnius: Technika (in Lithuanian).

Turskis, Z.; Zavadskas, E. K.; Peldschus, F. 2009. Multi-criteria optimization system for decision making in construction design and management, Inzinerine Ekonomika - Engineering Economics (1): $7-17$.

Turskis, Z. 2008. Multi-attribute contractors ranking method by applying Ordering of feasible alternatives of solutions in terms of preferability technique, Technological and Economic Development of Economy 14(2): 224-239. doi:10.3846/1392-8619.2008.14.224-239

Turskis, Z.; Ambrasas, G.; Kalibatas, D.; Barvidas, A. 2007. Multiple criteria decision support system model for construction works technological cards designing, in The 9th International Conference "Modern Building Materials, Structures and Techniques". Vol. 1-3. Ed. by M. J. Skibniewski; P. Vainiunas, E. K. Zavadskas, May 16-18, 2007, Vilnius, Lithuania. Vilnius: Technika, 381-391.

Tvaronavičienè, M.; Ginevičius, R.; Grybaitè, V. 2008. Comparisons of Baltic countries' development: practical aspects of complex approach, Verslas: teorija ir praktika [Business: Theory and Practice] 9(1): 51-64. doi:10.3846/1648-0627.2008.9.51-64

Urbanavičienè, V. 2009. The housing quality and price equilibrium: the negotiation model and the system: summary of doctoral dissertation Vilnius: Technika.

Urbanavičienè, V.; Kaklauskas, A.; Zavadskas, E. K. 2009a. The conceptual model of construction and real estate negotiation, International Journal of Strategic Property Management 13(1): 53-70. doi:10.3846/1648-715X.2009.13.53-70

Urbanavičienė, V.; Kaklauskas, A.; Zavadskas, E. K.; Seniut, M. 2009b. The web-based real estate multiple criteria negotiation decision support system: a new generation of decision support systems, International Journal of Strategic Property Management 13(3): 267-286. doi:10.3846/1648-715X.2009.13.267-286

Ustinovičius, L. 2007. Methods of determining objective, subjective and integrated weights of attributes, International Journal of Management and Decision-Making 8(5/6): 540-554.

doi:10.1504/IJMDM.2007.013417

Ustinovichius, L.; Kochin, D. 2008. The possibilities of verbal decision analysis methods for construction solutions, International Journal of Environment and Pollution 35(2/3/4): 366-384.

doi:10.1504/IJEP.2008.021366

Ustinovichius, L.; Shevchenko, G.; Barvidas, A.; Ashikhmin, I. V.; Kochin, D. 2010. Feasibility of verbal analysis application to solving the problems of investment in construction, Automation in Construction 19(3): 375-384. doi:10.1016/j.autcon.2009.12.004 
Ustinovichius, L.; Barvidas, A.; Vishnevskaja, A.; Ashikhmin, I. V. 2009. Multicriteria verbal analysis for the decision of construction problems, Technological and Economic Development of Economy 15(2): 326-340. doi:10.3846/1392-8619.2009.15.326-340

Ustinovichius, L.; Barvidas, A.; Vishnevskaja, A.; Ashikhmin, I. V. 2008a. Multicriteria verbal analysis for construction contracts, in The 20th International Conference, EURO Mini Conference "Continuous Optimization and Knowledge-Based Technologies" (EurOPT-2008): Selected papers. Ed. by L. Sakalauskas, G.-W. Weber, E. Zavadskas. May 20-23, 2008, Neringa, Lithuania. Vilnius: Technika, 235-240.

Ustinovichius, L.; Turskis, Z.; Shevchenko, G. 2008b. Multi-attribute analysis of investment risks in construction, in The 25th International Symposium on Automation and Robotics in Construction ISARC-2008: Selected papers. Ed. by E. Zavadskas, A. Kaklauskas, M. J. Skibniewski, June 26-29, 2008, Vilnius, Lithuania. Vilnius: Technika, 682-687. doi:10.3846/isarc.20080626.682

Ustinovicius, L.; Kochin, D.; Kutut, V.; Shevchenko G. 2008c. Verbal analysis of renovation investment strategy of old town, in The 25th International Symposium on Automation and Robotics in Construction ISARC-2008: Selected papers. Ed. by E. Zavadskas, A. Kaklauskas, M. J. Skibniewski, June 26-29, 2008, Vilnius, Lithuania. Vilnius: Technika, 397-410. doi:10.3846/isarc.20080626.397

Ustinovichius, L.; Barvidas, A.; Ashikhmin, I. 2007a. Verbal analysis of DSS UniCombos for engineering project models, in The 9th International Conference "Modern Building Materials, Structures and Techniques”, Vol. 1-3. Ed. M. J. Skibniewski; P. Vainiunas, E. K. Zavadskas, May 16-18, 2007, Vilnius, Lithuania. Vilnius: Technika, 392-400.

Ustinovičius, L.; Kochin, D.; Ševčenko, G. 2007b. Clara - expert verbal method of determining investment risk in construction, in The 9th International Conference "Modern Building Materials, Structures and Technique"s, Vol. 1-3. Ed. by M. J. Skibniewski; P. Vainiunas, E. K. Zavadskas, May 16-18, 2007, Vilnius, Lithuania. Vilnius: Technika, 408-413.

Ustinovičius, L.; Migilinskas, D.; Tamošaitienè, J.; Zavadskas, E. K. 2007c. Uncertainty analysis in construction project's appraisal phase, in The 9th International Conference "Modern Building Materials, Structures and Techniques”. Vol. 1-3. Ed. by M. J. Skibniewski; P. Vainiunas, E. K. Zavadskas, May 16-18, 2007, Vilnius, Lithuania. Vilnius: Technika, 401-407.

Ustinovichius, L.; Zavadskas, E. K.; Podvezko, V. 2007d. The application of a quantitative multiple criteria decision making (MCDM) approach to the analysis of investments in construction, Control and Cybernetic 36(2): 251-268.

Vaidogas, E. R.; Zavadskas, E. K. 2007. Introducing reliability measures into multi-criteria decisionmaking, International Journal of Management and Decision-Making 8(5/6): 475-496.

doi:10.1504/IJMDM.2007.013413

Vaidogas, E. R.; Zavadskas, E. K.; Turskis, Z. 2007. Reliability measures in multicriteria decisionmaking as applied to engineering projects, International Journal of Management and Decision-Making 8(5/6): 497-518. doi:10.1504/IJMDM.2007.013414

Vainiūnas, P.; Zavadskas, E. K.; Peldschus, F.; Turskis, Z.; Tamošaitienė, J. 2009. Model of construction design projects' managers qualifying by applying analytic hierarchy process and buyer's rule, in The 5th International Conference, EURO Mini Conference "Knowledge-Based Technologies and OR Methodologies for Strategic Decisions of Sustainable Development" (KORSD-2009): Selected papers. Ed. by M. Grasserbauer, L. Sakalauskas, E. K. Zavadskas. September 30-October 3, 2009, Vilnius, Lithuania. Vilnius: Technika, 148-153.

Vilutiene, T. (Ed.). 2009. Proc. 12th German-Lithuanian-Polish Colloquium on Sustainable Development in Civil Engineering and Multi-Attribute Decision Making, May 23-25, 2009, Vilnius.

Vilutiene, T. 2008. Automated Processing of Subcontractor Work Performance Data to Improve the Quality Control and Support the Subcontractor Selection Process, in The 25th International Symposium on Automation and Robotics in Construction ISARC-2008: Selected papers, Ed. by E. Zavadskas, 
A. Kaklauskas, M. J. Skibniewski, June 26-29, 2008, Vilnius, Lithuania. Vilnius: Technika, 507-514. doi:10.3846/isarc.20080626.507

Vilutiene, T.; Turskis, Z. 2007. Multiple criteria analysis of foundation instalment alternatives, in The 9th International Conference "Modern Building Materials, Structures and Techniques". Vol. 1-3. Ed. by M. J. Skibniewski, P. Vainiunas, E. K. Zavadskas, May 16-18, 2007, Vilnius, Lithuania. Vilnius: Technika, 420-427.

Viteikienè, M. 2008. Multi-attribute assessment of sustainability of residential areas and the cities (on the example of Vilnius city): summary of doctoral dissertation. Vilnius: Technika.

Viteikienè, M.; Zavadskas, E. K. 2007. Evaluating the sustainability of Vilnius city residential areas, Journal of Civil Engineering and Management 13(2): 149-155.

Viteikienè, M.; Zavadskas, E. K.; Turskis, Z. 2007. Multiple-attribute evaluation of new construction influence on apartments ranking: case study of Vilnius city, in The 9th International Conference "Modern Building Materials, Structures and Techniques". Vol. 1-3. Ed. by M. J. Skibniewski, P. Vainiunas, E. K. Zavadskas, May 16-18, 2007, Vilnius, Lithuania. Vilnius: Technika, 428-432.

Wieckowski, A.; Skibniewski, M. J. 2008. Errors of Calculations in M/M/1/FIFO/N/F Model with Limited Duration of Shift, in The 25th International Symposium on Automation and Robotics in Construction ISARC-2008: Selected papers, Ed. by E. Zavadskas, A. Kaklauskas, M. J. Skibniewski, June 26-29, 2008, Vilnius, Lithuania. Vilnius: Technika, 708-716. doi:10.3846/isarc.20080626.708

Yetgin, F.; Lepkova, N. 2007. A comparative analysis on housing policies in Turkey and Lithuania, International Journal of Strategic Property Management 11(1): 47-64.

Zavadskas, E. K. 2010a. 25 ${ }^{\text {th }}$ International Symposium on Automation and Robotics in Construction, Automation in Construction 19: 285. doi:10.1016/j.autcon.2009.12.010

Zavadskas, E. K. 2010b. 25 $5^{\text {th }}$ Automation and Robotics in Construction: international research and achievements, Automation in Construction 19: 286-290. doi:10.1016/j.autcon.2009.12.011

Zavadskas, E. K. 2008a. Beginning the fifth decade of development, Journal of Civil Engineering and Management 14(4): 213-215. doi:10.3846/1392-3730.2008.14.19

Zavadskas, E. K. 2008b. History and evolving trends of construction colloquia on sustainability and operational research, Technological and Economic Development of Economy 14(4): 578-592. doi:10.3846/1392-8619.2008.14.578-592

Zavadskas, E. K. 2008c. Book review. Methods and models of research in construction project engineering, Journal of Business Economics and Management 9(3): 240-243.

doi:10.3846/1611-1699.2008.9.240-243

Zavadskas, E. K. 2008d. Optimization methods for a stakeholder society: Reviewed book: Willem K. Brauers. Optimization Methods for a Stakeholder Society: A Revolution in Economic Thinking by Multi-objective Optimization. Boston / Dordrecht / London: Kluwer Academic Publishers, 2004, Journal of Business Economics and Management 9(4): 335-337.

doi:10.3846/1611-1699.2008.9.335-337

Zavadskas, E. K. 2008e. Beginning a new stage of development, Technological and Economic Development of Economy 14(3): 241-243. doi:10.3846/1392-8619.2008.14.241-243

Zavadskas, E. K.; Antuchevičienè, J. 2007. Multiple criteria evaluation of rural buildings' regeneration alternatives, Building and Environment 42(1): 436-451. doi:10.1016/j.buildenv.2005.08.001

Zavadskas, E. K.; Burinskiene, M. 2007. Editorial. Special issue on external and internal housing environment, International Journal of Environment and Pollution 30(3-4): 359-362.

Zavadskas, E. K.; Kaklauskas, A. 2008a. The model for Lithuanian construction industry development, Transformations in Business \& Economics 7(1): 152-168.

Zavadskas, E. K.; Kaklauskas, A. 2008b. Advanced information and communication technologies in construction, in The 25th International Symposium on Automation and Robotics in Construction 
ISARC-2008: Selected papers. Ed. by E. Zavadskas, A. Kaklauskas, M. J. Skibniewski, June 26-29, 2008, Vilnius, Lithuania. Vilnius: Technika, 39-45. doi:10.3846/isarc.20080626.39

Zavadskas, E. K.; Kaklauskas, A. 2008c. Editorial. Special issue on external and internal housing environments: technological and facilities approach, International Journal of Environment and Pollution 35(2/3/4): 153-157.

Zavadskas, E. K., Kaklauskas, A. 2007. Mehrzielselektion für Entscheidungen im Bauwesen. Fraunhofer, Stuttgart: IRB Verlag.

Zavadskas, E. K.; Turskis, Z. 2008. A New logarithmic normalization method in Games Theory, Informatica 19(2): 303-314.

Zavadskas, E. K.; Vaidogas, E.-R. 2009. Multi-attribute selection from alternative designs of infrastructure components for accidental situations, Computer-Aided Civil and Infrastructure Engineering 24(5): 346-358. doi:10.1111/j.1467-8667.2009.00593.x

Zavadskas, E. K.; Vaidogas, E. R. 2008. Managerial decisions about alternative automatic equipment for disaster management in construction, in The 25th International Symposium on Automation and Robotics in Construction ISARC-2008: Selected papers. Ed. by E. Zavadskas, A. Kaklauskas, M. J. Skibniewski, June 26-29, 2008, Vilnius, Lithuania. Vilnius: Technika, 737-743.

doi:10.3846/isarc.20080626.737

Zavadskas, E. K.; Kaklauskas, A.; Turskis, Z.; Kalibatas, D. 2009a. An approach to multi-attribute assessment of indoor environment before and after refurbishment of dwellings, Journal of Environmental Engineering and Landscape Management 17(1): 5-11. doi:10.3846/1648-6897.2009.17.5-11

Zavadskas, E. K.; Kaklauskas, A.; Turskis, Z.; Tamosaitiene, J. 2009b. Multi-attribute decision-making model by applying Grey numbers, Informatica 20(2): 305-320.

Zavadskas, E. K.; Kaklauskas, A.; Vilutienè, T. 2009c. Multicriteria evaluation of apartment blocks maintenance contractors: Lithuanian case study, International Journal of Strategic Property Management 13(4): 319-338. doi:10.3846/1648-715X.2009.13.319-338

Zavadskas, E. K.; Mikšta, P.; Sakalauskas, R.; Šimkus, J. R.; Ustinovičius, L. 2009d. Construction organization. 2nd ed. Vilnius: Technika (in Lithuanian).

Zavadskas, E. K.; Peldschus, F.; Turskis, Z.; Tamošaitiene, J. 2009e. The values of the equilibrium point for the sustainable decision making in construction, in The 5th International Conference. EURO Mini Conference "Knowledge-Based Technologies and OR Methodologies for Strategic Decisions of Sustainable Development" (KORSD-2009): Selected papers. Ed. by M. Grasserbauer, L. Sakalauskas, E. K. Zavadskas. September 30 - October 3, 2009, Vilnius, Lithuania. Vilnius: Technika, 154-158.

Zavadskas, E. K.; Kaklauskas, A.; Raslanas, S.; Galiniene, B. 2008a. Web-based intelligent DSS for real estate, International Journal of Environment and Pollution 35(2/3/4): 250-264.

doi:10.1504/IJEP.2008.021359

Zavadskas, E. K.; Kaklauskas, A.; Seniut, M.; Dzemyda, G.; Ivanikovas, S.; Stankevic, V.; Simkevicius, C.; Jarusevicius, A. 2008b. Web-Based Biometric Mouse Intelligent System for Analysis of Emotional State and Labour Productivity, in The 25th International Symposium on Automation and Robotics in Construction ISARC-2008: Selected papers, Ed. by E. Zavadskas, A. Kaklauskas, M. J. Skibniewski, June 26-29, 2008, Vilnius, Lithuania. Vilnius: Technika, 429-434.

doi:10.3846/isarc.20080626.429

Zavadskas, E. K.; Kaklauskas, A.; Skibniewski, M. J. (Eds.). 2008c. The 25th International Symposium on Automation and Robotics in Construction (ISARC-2008): Selected papers. June 26-29, 2008, Vilnius, Lithuania, Vilnius: Technika.

Zavadskas, E. K.; Kaklauskas, A.; Tupenaite, L.; Mickaityte, A. 2008d. Decision-making model for sustainable buildings refurbishment. Energy efficiency aspect, in The 7th International Conference "Environmental Engineering": Selected papers, Vol. 2. Ed. by D. Cygas, K. D. Froehner. May 22-23, 2008, Vilnius, Lithuania. Vilnius: Technika, 894-901. 
Zavadskas, E. K.; Kaklauskas, A.; Turskis, Z.; Kalibatas, D. 2008e. Multi attribute assessment of dwelling houses renovation, in The 7th International Conference "Environmental Engineering": Selected papers, Vol. 2. Ed. by D. Cygas, K. D. Froehner. May 22-23, 2008, Vilnius, Lithuania. Vilnius: Technika, 902-906.

Zavadskas, E. K.; Kaklauskas, A.; Turskis, Z.; Tamošaitienè, J. 2008f. Selection of the effective dwelling house walls by applying attributes values determined at intervals, Journal of Civil Engineering and Management 14(2): 85-93. doi:10.3846/1392-3730.2008.14.3

Zavadskas, E. K.; Kaklauskas, A.; Turskis, Z.; Tamosaitiene, J. 2008g. Contractor selection multiattribute model applying COPRAS method with Grey interval numbers, in The 20th International Conference, EURO Mini Conference "Continuous Optimization and Knowledge-Based Technologies" (EurOPT-2008): Selected papers. Ed. by L. Sakalauskas, G.-W. Weber, E. Zavadskas. May 20-23, 2008, Neringa, Lithuania. Vilnius: Technika, 241-247.

Zavadskas, E. K.; Kaklauskas, A.; Turskis, Z.; Tamosaitiene, J.; Kalibatas, D. 2008h. Assessment of indoor environment applying COPRAS method with attributes determined at intervals, in The 7th International Conference "Environmental engineering": Selected papers, Vol. 2. Ed. by D. Cygas, K. D. Froehner. May 22-23, 2008 Vilnius, Lithuania. Vilnius: Technika, 907-912.

Zavadskas, E. K.; Karablikovas, A.; Malinauskas P.; Mikšta, P.; Nakas, H.; Sakalauskas, R. $2008 \mathrm{.}$ Technology of Construction Processes, 2nd Ed. Vilnius: Technika (in Lithuanian).

Zavadskas, E. K.; Krutinis, M.; Kaklauskas, A.; Vainiunas, P.; Naimaviciene, J.; Povilaityte, L. Tupenaite, L. 2008j. Model for multiple criteria analysis of integrated intelligent and built-up ambient assisted living environment, in The 25th International Symposium on Automation and Robotics in Construction ISARC-2008: Selected papers Ed. by E. Zavadskas, A. Kaklauskas, M. J. Skibniewski, June 26-29, 2008, Vilnius, Lithuania. Vilnius: Technika, 725-730. doi:10.3846/isarc.20080626.725

Zavadskas, E. K.; Liias, R.; Turskis, Z. 2008k. Multi-attribute decision-making methods for assessment of quality in bridges and road construction: State-Of-The-Art Surveys, The Baltic Journal of Road and Bridge Engineering 3(3): 152-160. doi:10.3846/1822-427X.2008.3.152-160

Zavadskas, E. K.; Naimaviciene, J.; Kaklauskas, A.; Krutinis, M.; Vainiunas, P. 20081. Multi-criteria decision support system of intelligent ambient assisted living environment, in The 25th International Symposium on Automation and Robotics in Construction ISARC-2008: Selected papers, Ed. by E. Zavadskas, A. Kaklauskas, M. J. Skibniewski, June 26-29, 2008, Vilnius, Lithuania. Vilnius: Technika, 717-724. doi:10.3846/isarc.20080626.717

Zavadskas, E. K.; Peldschus, F.; Turskis, Z. 2008m. Multi-criteria optimization software LEVI-4.0 a tool to support design and management in construction, in The 25th International Symposium on Automation and Robotics in Construction ISARC-2008: Selected papers, Ed. by E. Zavadskas, A. Kaklauskas, M. J. Skibniewski, June 26-29, 2008, Vilnius, Lithuania. Vilnius: Technika, 731-736. doi:10.3846/isarc.20080626.731

Zavadskas, E.; Raslanas, S.; Kaklauskas, A. 2008n. The selection of effective retrofit scenarios for panel houses in urban neighbourhoods based on expected energy savings and increase in market value: The Vilnius case, Energy and Buildings 40(4): 573-587. doi:10.1016/j.enbuild.2007.04.015

Zavadskas, E. K.; Trinkunas, V.; Kaklauskas, A. 2008o. Reasoned decisions in construction materials selection, in The 25th International Symposium on Automation and Robotics in Construction ISARC-2008: Selected papers, Ed. by E. Zavadskas, A. Kaklauskas, M. J. Skibniewski, June 26-29, 2008, Vilnius, Lithuania. Vilnius: Technika, 528-532. doi:10.3846/isarc.20080626.528

Zavadskas, E. K.; Turskis, Z.; Tamošaitienè, J. 2008p. Contractor selection of construction in a competitive environment, Journal of Business Economics and Management 9(3): 181-187. doi:10.3846/1611-1699.2008.9.181-187

Zavadskas, E. K.; Turskis, Z.; Tamošaitienè, J.; Marina, V. 2008q. Multicriteria selection of project managers by applying grey criteria, Technological and Economic Development of Economy 14(4): 462-477. doi:10.3846/1392-8619.2008.14.462-477 
Zavadskas, E. K.; Turskis, Z.; Tamosaitiene, J.; 2008r. Construction risk assessment of small-scale objects by applying TOPSIS method with attributes value determined at intervals, Computer Modelling and New Technologies 12 (4): 38-43.

Zavadskas, E. K.; Turskis, Z.; Tamosaitiene, J.; Marina, V. 2008s. Selection of construction project managers by applying CORAS-G method, Computer Modelling and New Technologies 12(3): 22-28.

Zavadskas, E. K.; Kaklauskas, A.; Kaklauskiené, J. 2007a. Modelling and forecasting of a rational and sustainable development of Vilnius: emphasis on pollution, International Journal of Environment and Pollution 30(3/4): 485-500. doi:10.1504/IJEP.2007.014824

Zavadskas, E. K.; Kaklauskas, A.; Peldschus, F.; Turskis, Z. 2007b. Multi-attribute Assessment of Road Design Solutions by Using the COPRAS Method, The Baltic Journal of Road and Bridge Engineering 2(4): 195-203.

Zavadskas, E. K.; Kaklauskas, A.; Šaparauskas, J.; Kalibatas, D. 2007c. Evaluation of Vilnius urban sustainability with special emphasis on pollution, Ekologija 53(Suppl.): 64-72.

Zavadskas, E. K.; Kaklauskas, A.; Vlasenko, A.; Gulbinas, A. 2007d. Intelligent library and tutoring system for Brita in PUBs project, in The 9th International Conference "Modern Building Materials, Structures and Techniques". Vol. 1-3. Ed. by M. J. Skibniewski, P. Vainiunas, E. K. Zavadskas, May 16-18, 2007, Vilnius, Lithuania. Vilnius: Technika, 433-437.

Zavadskas, E. K.; Karablikovas, A.; Kriukelis, V.; Nakas, H.; Sakalauskas, R. 2007e. Construction Technology. 2nd ed. Vilnius: Technika (in Lithuanian).

Zavadskas, E. K.; Raslanas, S.; Kaklauskas, A. 2007f. Evaluation of building retrofit projects, in The 9th International Conference "Modern Building Materials, Structures and Techniques". Vol. 1-3. Ed. by M. J. Skibniewski, P. Vainiunas, E. K. Zavadskas, May 16-18, 2007, Vilnius, Lithuania. Vilnius: Technika, 438-441.

Zavadskas, E. K.; Turskis, Z.; Antuchevičienė, J.; Tamošaitienė, J. 2007g. Assesment of individual residential building external walls alternatives applying TOPSIS method, in The 9th International Conference "Modern Building Materials, Structures and Techniques". Vol. 1. Ed. by M. J. Skibniewski, P. Vainiunas, E. K. Zavadskas, May 16-18, 2007, Vilnius, Lithuania. Vilnius: Technika, 442-446.

Zavadskas, E. K.; Viteikiene, M.; Šaparauskas, J. 2007h. Sustainable development assessment of cities and their residential districts, Ekologija 53(Suppl.): 49-54.

Zavrl, M. S.; Zarnic, R.; Selih, J. 2009. Multicriterial sustainability assessment of residential buildings, Technological and Economic Development of Economy 15(4): 612-630.

doi:10.3846/1392-8619.2009.15.612-630

\section{VOKIETIJOS - LIETUVOS - LENKIJOS MOKSLINIO TRIKAMPIO BENDRADARBIAVIMO REZULTATAS - NAUJAS ETAPAS OPERACINIŲ TYRIMU STATYBOS INŽINERIJOJE IR DARNIOS PLĖTROS SRITYSE}

\section{J. Tamošaitienė, L. Bartkienė, T. Vilutienė}

Santrauka

Straipsnyje apžvelgiami mokslinio bendradarbiavimo rezultatai tarp Vokietijos, Lietuvos ir Lenkijos akademinių centrų. Šių centrų susitikimai buvo vadinami kolokviumais, kurie buvo organizuojami kas antrus metus skirtingame akademiniame centre. Šiame straipsnyje apžvelgiami moksliniai pasiekimai ir nuveikti darbai 2007-2009 m., pateikiami Vokietijos, Lietuvos ir Lenkijos akademinių centrų atlikti darbai operaciniu tyrimu, statybos inžinerijos ir subalansuotos plètros temomis. Produktyvaus bendradarbiavimo rezultatai nuo 11-ojo iki 12-ojo kolokviumo yra: apgintos habilitacinių darbų tezès bei daktaro disertacijos, paskelbti moksliniai straipsniai ir išleistos knygos, suorganizuotos mokslinès kon- 
ferencijos ir išspausdinti konferencijų straipsnių rinkiniai. Remiantis šiais pasiekimais buvo įsteigta darbo grupe „OR in Sustainable Development and Civil Engineering“ (EWG-ORSDCE).

Reikšminiai žodžiai: bendradarbiavimas, darna, operacijų tyrimai, statybos inžinerija, plètra.

Jolanta TAMOŠAITIENĖ. Doctor, Dean assistant of Civil Engineering Faculty, Vilnius Gediminas Technical University, lecturer of the Dept of Construction Technology and Management, Vilnius Gediminas Technical University, Lithuania. BSc degree (building technology and management), Vilnius Gediminas Technical University (2000). MSc degree (Building management and economics), Vilnius Gediminas Technical University (2002). She is a member of EURO Working Group "OR in Sustainable Development and Civil Engineering". She has published 10 scientific papers. Research interests: construction technology and organisation, construction project administration, decision-making and grey theory.

Lina BARTKIENĖ. PhD student in the Dept of Construction Economics and Property Management at Vilnius Gediminas Technical University. Research intrests: job performance, organizational effectiveness.

Tatjana VILUTIENE. Doctor, Assoc. Prof. in the Dept of Construction Technology and Management at Vilnius Gediminas Technical University, Vilnius, Lithuania. She is the coordinator of EURO Working Group „OR in Sustainable Development and Civil Engineering“. She is and has been a member of organizing committees at international conferences. She is the author of 1 textbook for students published in Lithuanian and about 20 scientific papers. Her research interests include decision-making in construction, project management in construction, facilities management, and quality management. 